Historic, Archive Document

Do not assume content reflects current scientific knowledge, policies, or practices. 


\section{ELECTRIC CITY CONSERVATORY, InC.}

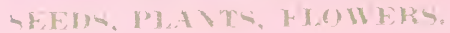

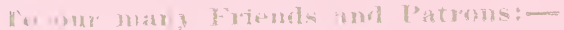

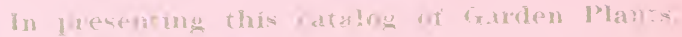
arubs axel Bulbs. we wish to thank, yor for vous satmenasy in rlie past mel to assure you that any

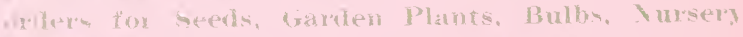

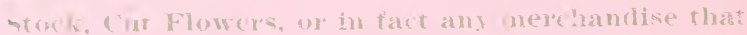
we tarry will he strietly rirst class and will be

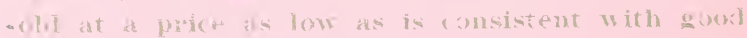

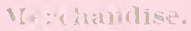

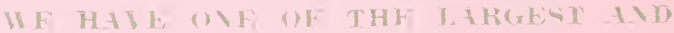

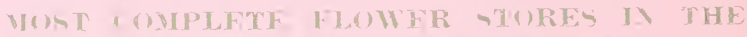

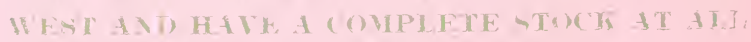

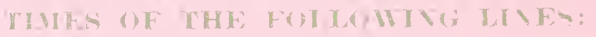

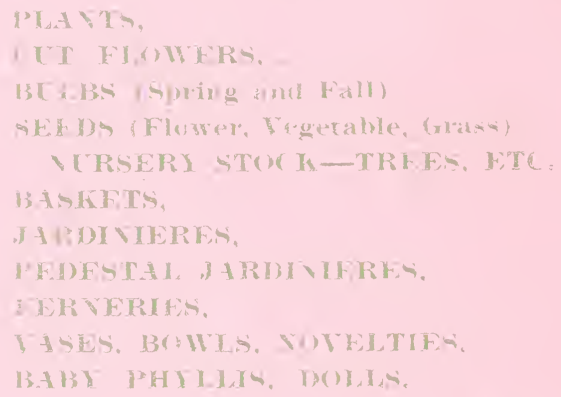

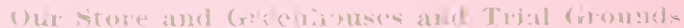

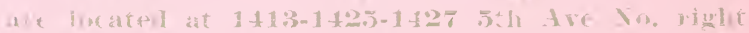

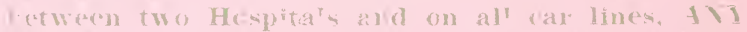

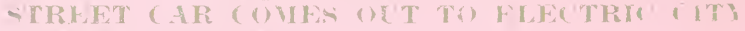

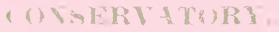

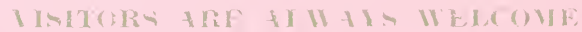

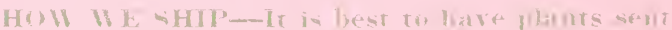

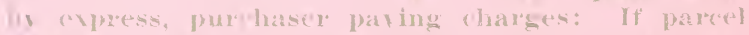

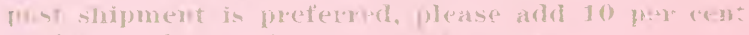

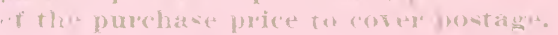

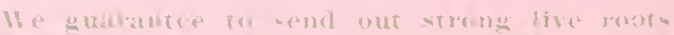
and flints, so thut with orindil care in planting

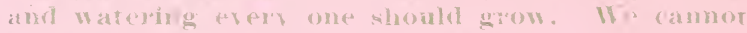

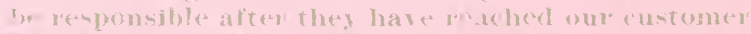
(n) gend romolitim. Tlise are so mans comditions wrer whieh we hor" no rontrel, such as peson seil.

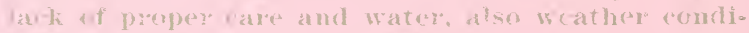

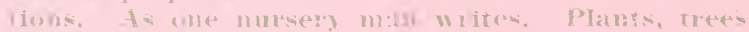
(1) thrules are a living astuism, wheh as a cove,

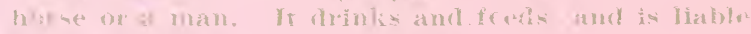

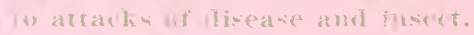

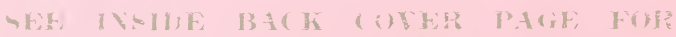

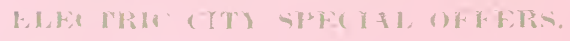




\section{ANNUAL FLOWERING PLANTS}

\section{For Bedding, Window Boxes and Hanging Baskets.}

We make window and porch box planting a specialty. This season we are equipped to make the boxes in our own shop. We also have to offer Hanging Baskets, in three different sizes, ranging in price from $\$ 1.25$ to $\$ 3.00$ each.

Any of the Annuals Except where noted 50c per dozen

Asters-in beauty asters rank next to peonies and roses. They are extraordinary when planted in masses. More hardy than cabbage and can be set out quite early. We are offering only the choicest strains. "Sunslaine" Their delicate beauty is hard to describe, some of the petals are twisted and quilled, colors, blue, pink, lilac and white.

California Giants-A new family of asters, lovely shades of dark rose, dark purple, light-blue and peach-blossom. Balls White Aster one of the purest of all whites. Heart of France, opens red as the purest ruby, very showy. Sensation, dark rich garnet or ox-blood red. The Crego Asters are giants in size, all colors. Per Dozen 50c

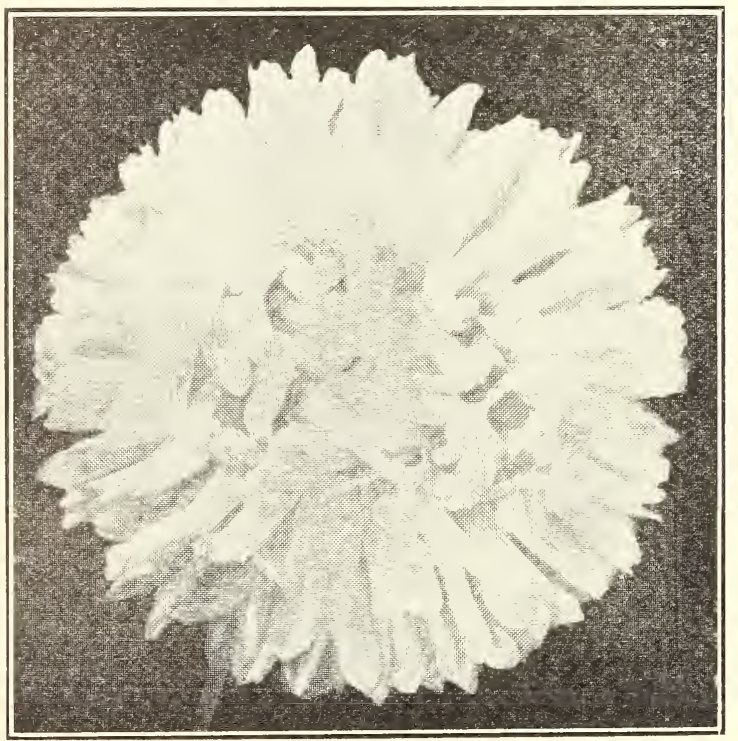

ASTER

Aretotis,-(African Daisy) Color lavendar.

African Marigold-Tall kinds, orange and lemon yellow.

Calliopsis-Fine for cutting lovely shades of yellow and brown.

Celandula-(Pot Marigold) one of our most popular annuals, all shades of yellow. 


\section{ANNUAL FLOWERING PLANTS}

Mignonette-(Fine Manchet) No garden is complete without this sweetest of "old fashioned" flowers.

Pansy Plants-Extra Choice Plants, Finest mixture of colors, doz. 50 cents. In separate colors we have to offer Black, Yellow, Pink, Blue, Purple, Indigo Blue, Bronze, Violet Blue, Doz. 75c

Snapdragon-Yellow, light red and dark pink, maroon and rose.

Strawflower-Six separate colors, fine for winter bouquets.

Stocks-Assorted colors

Sweet Alysum-Carpet of snow, fine for edging sweet scented, blooms all summer.

Price of any of the above, except where noted; sc each, 2 inch pots, 50c per doz.-3 inch pots 75e per doz.

Petunias-All colors, 3 inch pots, each ?oc, 4 inch pots 350 each.

Petunias not in pots $\$ \mathbf{1 . 0 0}$ per dozen.

Geraniums-All colors, choice plants, 2 inch pots 10 cents, 3 inch pots 20 cents each.

Geraniums-Four different shades of red, three shades of pink, and white, 4 inch pots $\mathbf{3 5}$ cents 5 inch pots $\mathbf{7 5}$ cents.

Rose Leaved Geranium-For jelly flavoring, choice plants 25 cents each.

Nasturtiums-Tall climbing variety and dwarf varieties, 2 inch pots $50 \mathrm{c}$ per dozen.

Vincas-Green and White, useful for window boxes and hanging baskets, 4 inch pots $\mathbf{P B 5}$ and $\mathbf{5 0}$ cents each, 5 inch pots 65 cents each.

Dracaenas-Rank among the most beautiful and useful of the ornamental foliaged and fine leaved plants. Used extensively for baskets and window boxes 50c, 75c and $\$ 1.00$ each.

Verbena-Many lovely shades, fragrant, fine for the window box as well as the garden 5c each 50c per dozen.

Lobelia_-"Crystal Palace" Fine for blue border, 5c each, 50c per dozen.

Tennia-Few of our annual garden flowers produce such a gorgeous display, 5c each 2 inch pots 50 cents per doz. 3 inch pots $\mathbf{7 5}$ cents per doz,

Huchsia-Assorted colors 3 inch pots 25 c, 4 inch pots 35 cents each. 


\section{ANNUAL FLOWERING PLANTS}

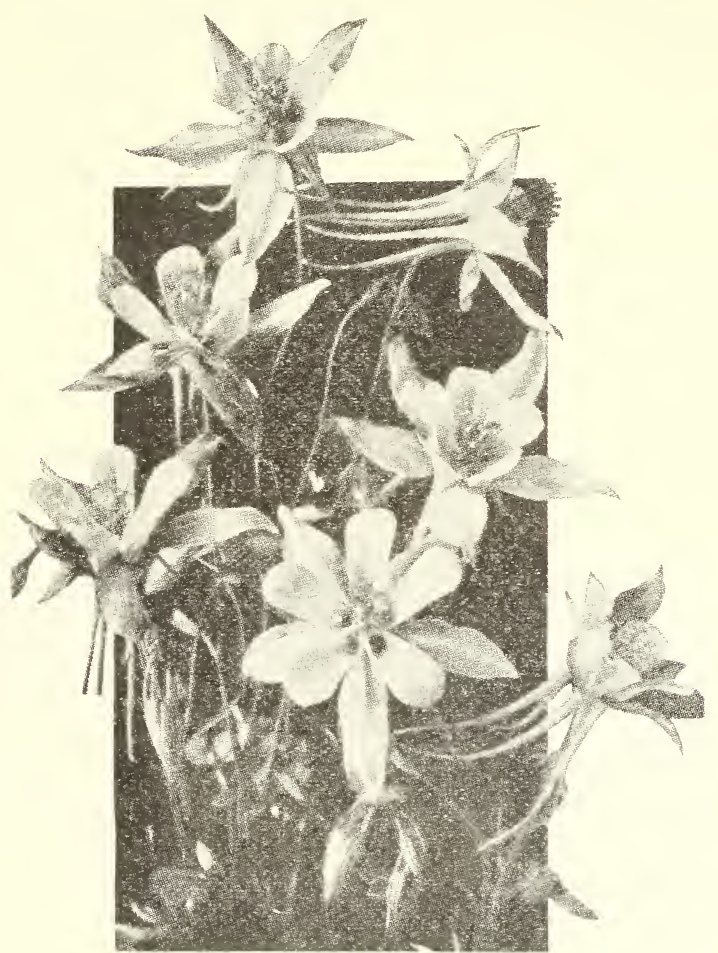

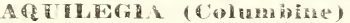

Asparagus Sprengeri-Fern, 50 cents each.

Castor Oil Bean-25c each, 2 inch pots \$2.50 per dozen.

Marguerites-Mrs. F. Sanders-White double and single 20c \& 30c each new double Marguerite

"Mother's Day" 50 cents each.

\section{HARDY PERENNIALS}

No garden is complete without these dear "old fashioned" hardy plants. Ideal flower for borders along walks and driveways. Some varieties are splendid for foundation planting, live on year after year and do not have to be taken up in winter.

We have many beautiful kinds to offer. Any of the perennials listed, $\mathbf{2 5 c}$ and $\mathbf{3 5 0}$ except where noted.

Achillea The Pearl-Pure white, fine for cutting blooms all summer.

Achillea Roseum-A pink variety.

Any of the perennials listed, 25c and 35c except where noted. 


\section{HARDY PERENNIALS}

Boltonia-Aster like hardy plant 4 to 6 feet high, white.

Boltonia-Latis Quama, delicate pink tinged with lavendar.

Coreopsis-One of our most popular hardy plants, flowers rich golden yellow beautiful graceful form.

Dianthus-Grass pink, should be planted in quantities, sweet scented free flowering.

Bleeding Heart-An old fashioned favorite, heart shaped rose, crimson flowers, each \$1.00

Dianthus Allwoodii-Everblooming Carnation.

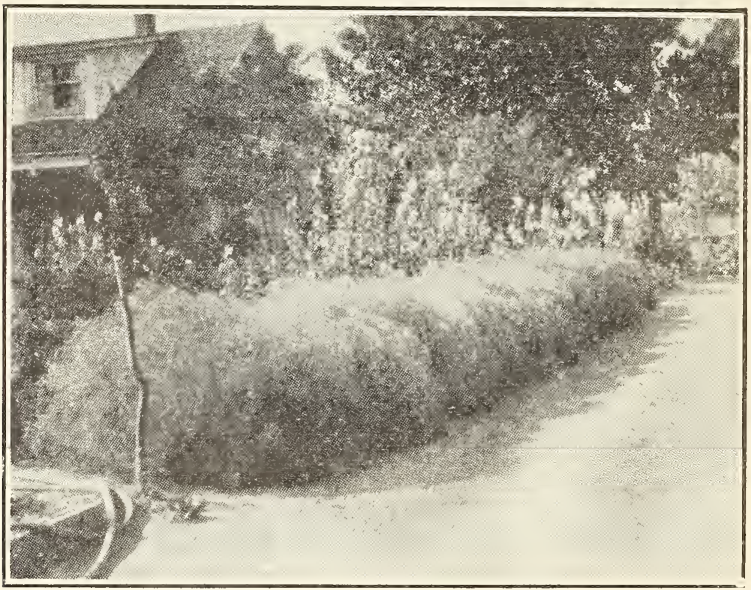

GYPSOPHILA (Baby's Breath)

Hardy Red Carnation-Everblooming hybrid, best to be had, each $\mathbf{2 5 c}$ and 50c.

Gypsophila-Baby's breath, 2 to 3 feet, white lacelike effect, nothing livelier for bouquets and for drying for winter bouquets each $20 \mathrm{c}$ large clumps $50 \mathrm{c}$ each.

Gaillardia-Blanket flower, crimson centers and yellow tips, long stems, long flowing period, each $15 \mathrm{c}$ and $25 \mathrm{c}$.

Gaillardia-Stand-holder, large flowers, up to 5 inches in diameter, yellow bordered with dark red wings each 35c and 50c.

Geum-Mrs. Bradshaw-Double orange scarlet flowers, very large and full each 35c.

Any of the perennials listed, 25c and 35c except where noted. 


\section{HARDY PERENNIALS}

Garden Heliotrope-White, highly valued for the fragrance of their flowers and long period of bloom, each 25c.

Golden Rod-Solidago, gracefully arched sprays of golden yellow flowers, and who does not love the Golden Rod, each. 25c.

Golden Glow-Laciniata, double golden yellow flowers 6 feet. July to September.

Helenium-Autumnal Superbum, A free and continous flowering plant, spreading heads of daisy like flowers 6 to 8 feet tall.

Hemerocallis-Day Lily, very ornamental foliage, graceful spikes of lily like flowers, grow better each year.

Lilium Regal-New variety from China, one of the most beautiful garden lilies, perfectly hardy, delicately scented flowers, ivy-white, shaded pink with canary yellow at base of petals small bulbs each 15c, two for 25c.

Lilium Tiger-The dear old fashioned lily of our grandmother's garden, single 25c, double 35c.

Lychinis-Ragged Robin, Chalcedonica, fiery red very beautiful, 3 to 4 feet.

Nepeta Mussini-Little plants covered with light blue flowers, fine for edging and an excellent rock plant.

Kelwayi Anthemis, Tinctoria-Rich yellow daisylike flowers, 2 feet June to September.

Physostegia Virginiana-Spikes of white flowers 4 to 5 feet June to July.

Snapdragon-Dense bushes with spikes of delicate pink tubular flowers, 3 feet.

Pyrethrum-Painted Daisy, rose color, one of our most valuable early summer flower's, May to September.

Red Mint Monarda-(Bergamont) Aromatic foliage, with bright red flowers 2 to $3 \mathrm{ft}$. July to August.

Any of the perennials listed, 25c and 35c except where noted. 


\section{HARDY PERENNIALS}

Ranuculus-(Crows-foot Buttercup) double flowered form of our common buttercup lovely.

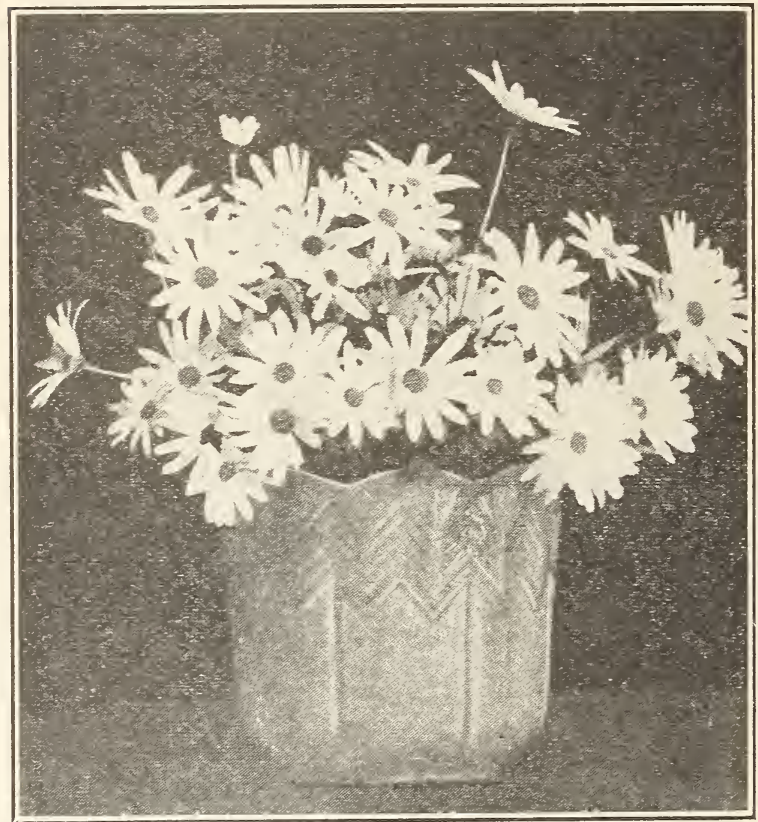

SHASTA DISIES

Shasta Daisy Alaska-Wonderfully large white flowers, long stems, fine for cutting $25 \mathrm{c}$, 35c and 50c each.

Shasta Daisy Alpine-Hardiest of all.

Scabiosa Japonica-2 ft. high lavender flowers

Sedum-Dwarf rock plant fine for banks and walks will flourish anywhere and stand dry weather.

Salvia Meadow Sage-Bushy plants 3 feet. high, covered all summer \& fall with dazzling scarlet flowers.

Salvia Azurea-Grandiflora, tall spikes of sky-blue flowers, 3 to 4 feet August and September.

Spiraea, "Goats Beari" (Meadow Sweet) beautiful border plants, with feathery white plumes of lovely flower's, each 60c \& $\mathbf{7 5 c}$.

Sweet Williams Dianthus Barbatus every one loves this old fashioned flower, red and pink.

Any of the perennials listed, 25e and 350 except where noted. 


\section{HARDY PERENNIALS}

Sun INower-Hardy Helianthus, a beautiful race of Sunflower plant, fine for cutting, does well anywhere.

Thalictrum Dipterompum-A new introduction from China, very graceful plumes of rosy-purple flowers 4 to 5 feet each 350 e $\&$ 5or.

Tritoma Red Hot Poker-Handsome border plants flowers borne in compact form on stout stems, 3 to $4 \mathrm{ft}$. tall, having the appearance at a distance of orange and red colored spear heads.

Lily of the Valley-Universally admired for their dainty little pure white bell shaped fragrant flowers, plant in a shady moist location, roots each 10c, dozen \$1.00.

statice-(Sea Lavender) large spreading panicles of light blue graceful flowers, these if cut and dried, will last in perfect condition for months each 2.5c, extra large 60c.

Penstemon-Beards Tongue Sensation A beautiful strain bearing spikes of large Gloxinia-like flowers.

Centaurea, Montana-Grows 2 feet high, bearing large violet blue flowers, June to September.

Sweet Rocket, (Hesperis' fragrant, producing large spikes of blossoms varying from white to lilac.

Physalis-Chinese lantern plant ornamental variety of the white cherry, dense bushes $2 \mathrm{ft}$. high, producing freely its bright orange-scarlet, lanternlike fruit, very interesting, each $\mathbf{3 5} \mathrm{c}$.

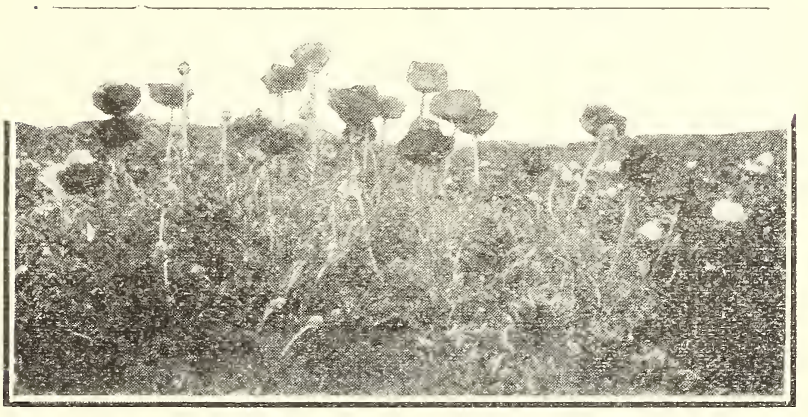

ORIENTAL POEIPIES

Oriental Poppy-Red and pink, gorgeous flowers each 25c, extra large clumps 60c.

Columbines- (Aquiligia) One of the most beautiful of our hardy perennials, and the first to bloom in the spring, splendid for cutting plant in shady corners. We have to offer the following varieties

Any of the peremnials listed, 2ăc and 35c except where noted. 


\section{PERENNIAL PHLOX}

Hayon-Strong grower $2 \mathrm{ft}$. color a rosy lavender white eye.

Miss Lingard-One of the best, has fragrant white flowers with faint lilac eye-early.

Mrs. Jinkins-The best all around pure white.

Siebold-Vivid orange-scarlet strong grower.

Compote, Freuch Purple-Very good. each 25c, extra large 35 c.

\section{GERMAN IRIS OR "FLEUR-DE-LIS"}

Double your garden joys with this lovely early spring flower.

Moori-King-Standards, rich golden-yellow, Falls velvety crimson gold. The most brilliant in this section.

Dorothea-Milky white, tinged lilac.

Gertrude-Deep violet-blue very fragrant.

Monsignor-S, bluish lavender, $\mathbf{F}$, violet, with white pencilings at throat, immense size and blooms for a long time.

Florentina-S, white, F, white faintly flushedlavender.

Loreley - S, light yellow $\mathrm{F}$, ultramarine, bordered cream, free flowering.

Her Majesty-S, rose-pink, F, pink with crimson vains.

Storm-Cloud-Large flowers with grayish slate blue with bronze shading.

Caprice-S, reddish purple, F, deeper self colored one of the best red irises.

Rhein Nixe-S, white, very large, F, rich violetpurple with distinct narrow white edge, beautiful in masses.

Prosper Langier-Mid-season, S, firy-bronze, F, velvety ruby purple like a pansy bloom.

Jeanne-De-Arc-Flowers large, petals broad of a fresh clear lilac, S, ruffed, F, pure white bordered lilac.

Zephyr-Fragrant clear blue lilac, very beautiful.

Landi Laprie-S, streaked purple $\mathbf{F}$, white blotched purple.

Elk's Purple-A lovely flower, exquisite light blue. 


\section{GERIMAN IRIS OR "FLEUR-DE-LIS"}

Foster's-Creamy yellow.

Queen of May-Soft shade of pink.

l'ress Thiers-Lovely shade of purple, blotchedpurple on white, each $\mathbf{2 5 c}$, extra large clumps 50c one lot of extra choice mixed colors, each $20 \mathrm{c}$ or $\$ 2.00$ per dozen.

\section{ROSES}

Crusader-A strong grower, beautiful large double flowers of a rich velvety crimson color, 75c to $\$ 1.25$ each.

Columbia-Splendid large double rose very lasting colors vary from peach-pink to brilliant rose-pink 75c to $\$ 1.25$ each.

Ophelia_Salmon flesh color, shaded with rose, strong stems very lasting when cut, a splendid out door variety, $\mathbf{7 5 c}$ to $\$ \mathbf{1 . 2 5}$ each, $\$ \mathbf{1 2 . 0 0}$ per dozen. Any of the above named varieties I can

supply in extra choice greenhouse grown plants that will give you an abundance of lovely flowers in a short time from planting.

Prairie King Rose-The wonder red rose, Bright rosy red, blooms in clusters. Everblooming strong field grown plants, \$1.00 to \$1.25 each.

Dorothy Perkins-Climber, Clear shell pink. Flowers borne in clusters. One of the finest $\mathbf{7 5 c}$ to $\$ 1.25$ each.

Crimson Rambler-The well known Crimson cluster climber. Very effective when grown on pillars and trallises. Flowers produced from ground to tip. $\mathbf{7 5} \mathrm{c}$ to $\$ \mathbf{1 . 2 5}$ each.

\section{ORNAMENTAL SHRUBS}

Shrubs grow more beautiful as the years go by. Many are useful as a cut flower. Can be used as a dividing line between the flower and vegetable garden. As a background to a flower border, or hiding an unsightly building, fence or foundation.

Honeysuckle-Red, 2 to $3 \mathrm{ft}$. $75 \mathrm{c}$ and $\$ 1.00$ each, 3 to 4 ft. $\$ 1.00$ to $\$ 1.25$ each.

Honeysuckle-White, 2 to $3 \mathrm{ft}$. $75 \mathrm{c} \& \$ \mathbf{1 . 0 0}$ each, 3 to $4 \mathrm{ft}$. $\$ 1.00$ \& $\$ 1.25$ each.

"Lilac Time is Spring Time at its Best"

Tilac, Common Purple-2 to 3 ft. 75 c \& $\$ 1.00$ each.

Lilac, Persian-Beautiful flowers of a reddish purple, \$1.25 \& \$1.50 each. 


\section{CLINBING VINES}

Grow "A vine over your door" nothing can take the place of vines in giving a house a home-like and livable appearance.

The following we have to offer are best suited to this locality.

Clematis-"Indian Smoke Vine" clean with a mass of fragrant white flowers in late summer does not die down in winter each 25c and 50c.

Bitter Sweet or Wax Work-With attractive light green foliage and yellow flowers, followed in autumn with bright orange fruit, 25c \& 50c.

Chinese Matrimony Vine-A hardy climber that will flourish everywhere, handsome purple flowers, later scarlet berries that hang on all winter 25c \& 50c.

Ampelopsis Quinquefolia-"Virginia Creeper or American Ivy, best for covering trees, trallises, Arbors, etc., 75c, \$1.00, \$1.50, extra choice \$2.50

Ampelopsis Veitchi-"Boston Ivy," fine for covering brick or stone work, clings without support $\$ 1.00 \& \$ 1.50$.

Engleman Ivy-Clinging Vines, each \$1.00 \& \$1.50

Clematis Jackmani-Beautiful large deep purple flowers the most reliable, \$1.25.

\section{DAHLIAS- "King of the Garden"}

Our Dahlia list consists only of the choicest and most popular varieties. The wonderful beauty of many defies description.

Please order by number

No. 1-Mrs. Dexter-Orange and red each 35c.

No. 2-Dreer's White-(Show) free flowering each 35c.

No. 3-Mina Burgle-(Decorative) rich dark scarlet long stems, each 35c.

No. 4-Attraction-(Decorative) Very beautiful large curled petals, soft mauve-rose, Cactus 75c.

No. 5-Hortulanus Fiet-(Decorative) Flowers over 8 in. in diameter of the most delicate shade of schrimp pink, each 75.

No.6-Buntens-(Decorative) Pink and yellow large flower, charming each 35c.

No. 7-Cabel Powers-Lovely shade light pink, each, 35c. 


\section{DAHLIAS- "King of the Garden"}

No. 8-Patrick O'Mara-(Decorative) Won a gold medal and has also.won high honors at many shows. Flowers large beautiful orangebuff slightly tinged with lovely deep rose color each, 50c.

No. 9-Golden West-(Cactus) A rich golden bronzy yellow scarlet shadings, each, 35c.

No. 10-J. W. Jackson-(Decorative) Deep velvety brick red each, 35c.

No. 11-Polar Bear-(Decorative) Large purest white each, 75c.

No. 12-Geasha Girl-(Decorative) Golden yellow center orange scarlet each $\mathbf{7 5 c}$.

No. 13-Maid of Kent--(Show) Varigated red and white each, 35c.

No. 14-Purple Manitou- (Decorative) Lovely each, 35c.

No. 15-King of Commerce-(Decorative) Rich tango, beautifully lighted, old gold and orange, each, 35c.

No. 16-Manitou Varigated- each, 50c.

No. 17-Countess of Lonsdale-(Cactus) A delicate apricot chading each 35c.

No. 18-Single Pink-Very good as a cut flower, each, 35c.

No. 19-American Beauty-(Show) each, 35c.

No. 20-Orange King-(Decorative) Rich glowing orange scarlet, each, 50c.

No. 21-Poupon Pink-(Show) each, 35c.

No. 22-Simi Single-Firey red each 35c.

No. 23-Yellow Cactus- each, 35c.

No. 24-Dr. Tyrrell-(Giant Decorative) Beautiful range bronze each 35c.

No. 25-Annabella-(Show) Sulphur yellow tipped and shaded old rose and lavender each 35c.

No. 26-Show-Rich red each, 50c.

No. 27-Cactus-White each 50c.

No. 28-Eterdnand De Lyon-(Cactus) Rich carmine rose each 35c.

No. 29-Large Cactus Red-Very choice each $\$ \mathbf{\$ 1 . 0 0}$ 


\section{DAHLIAS- "King of the Garden"}

No. 30-Semi Single White-(Cactus) each, 35c.

No. 31-Semi Śingle Mrs. Moore-Apricot with Salmon each, \$1.00.

No. 32-Cactus-Wine color, white tipped ea. 35c.

No. 33-Simi Single Red-each, 35c.

\section{PEONIES-“The Queen of Spring Flowers"}

Festiva Maxima-Finest White, Divisions 75c. Clumps \$1.00.

Edulus Superba-Deep rose-pink earliest of all, Divisions \$1.00, clumps \$1.50.

Queen Victoria-Pure white with cream center, Divisions 75c, clumps $\$ \mathbf{1 . 0 0}$

Duke of Wellington-Largest pure white, Divisions 75c, clumps \$1.00.

Mme. Ducel-Bright silvery pink salmon shadings Divisions \$1.00, clumps \$1.50.

Margurerite Gerard-Large flat flowers with broad petals, delicate pink, Divisions \$1.00, clumps $\$ 1.50$.

G. B. Gough-Sparkling red, Divisions $\$ \mathbf{\$ 1 . 0 0}$, clumps \$1.50.

Ruba Superba-Very large and double flower of a dark velvety crimson color, best for late flowering, Divisions \$1.00, clumps \$1.50.

Frau Karl Rosenfield-Brilliant dark crimson makes a wonderful show, Divisions \$1.50, clumps $\$ 2.00$.

Officinalis Ruba-most brilliant of all red peonies early, Divisions \$1.00, clumps \$1.50.

Officinalis Seperba-Beautiful shade of pink, early Divisions \$1.00, clumps \$1.50.

Triomphe De L Exposition De Lille-Very large compact, simi rose-typed, fragrant, free bloomer Division \$1.00, clumps \$1.50.

Bomb Type-Pink, Divisions \$1.00, clumps \$1.50.

Imperial Red-Lovely Divisions $\$ \mathbf{1 . 0 0}$ clumps $\mathbf{\$ 1 . 5 0}$

Iight Red-A most pleasing shade, Division 75e, clumps \$1.00.

H. B. Riddick-A gorgeous red flower, strong grower, Divisions \$1.00, clumps \$1.50.

We have a few extra large clumps of choice varieties, prices on application. 


\section{VEGETABLE PLANTS}

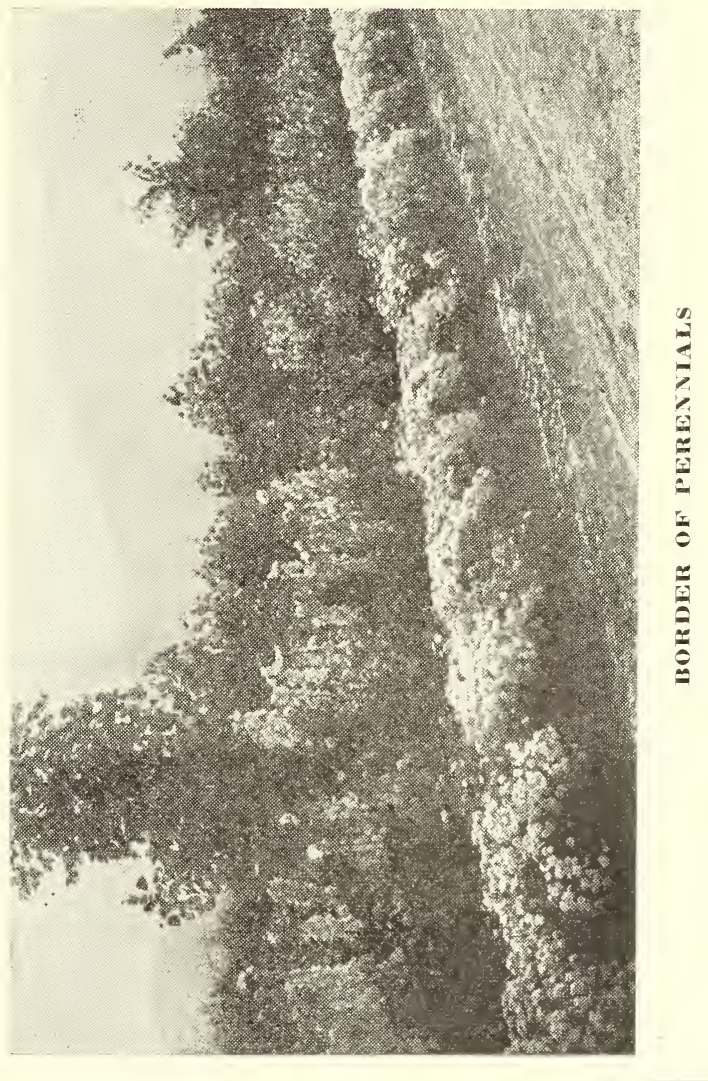

Our vegetable plants are grown from the choicest seed obtainable. While our list does not contain a large variety it is nevertheless complete and are those best suited for this climate.

Pepper-Harris earliest, sweet and mild adapted to the north, scarlet fruit, each 5c, doz. 50c.

Peppers-Red hots

Mint-Plants :uc each.

Sage-For flavoring, large clumps 25̄c each.

C'abbage-Plants all from the very best imported seed. Larly Golden Acre 25c per doz., \$1.50 per 100

Copenhagen Market-A second early cabbage hard solid with small core,15c per doz., \$1.00 per 100

Summer Ball Head-Fine for second planting, suited to all sections $\mathbf{1 5}$ c per doz., \$1.00 per 100 .

Iate Ball Head-Extremely popular làte cabbage, Handsome firm heads, best of keepers 15c per doz, $\$ \mathbf{1 . 0 0}$ per 100 . 


\section{VEGETABLE PLANTS}

All Season Cabbage-So called because it is as good for winter as for early summer 15c per doz., $\$ 1.00$ per 100 .

Earliest of All Cabbage-25e per doz., \$1.50 per 100

Red Stone Head-Fine for pickling and cooking, 20c per doz., \$1.00 per 100 .

Tomatoes-John Baer-Bright red fine flavor, one of the earliest.

Earliana-Early scarlet fruited of fine quality.

Dwarf Champion-Glossy purple, solid thick flesh, adapted to small gardens.

Yellow Sunrise-Best of the yellow fruited tomatoes superior flavor.

Bonny Best-A splendid sort, good shipper, transplanted plants 50c per doz., 3 in. pots $75 \mathrm{c}$ per doz 4 inch. pots $\$ 1.50$ per doz.

Asparagus Roots-Mary Washington, rust proof, 50c per dozen.

Rlubarb-Divisions $\mathbf{2 0}$ each, large clumps 50c.

Chives-15c each, large clumps 50c each.

Egg Plants-Pot grown 50c per doz.

Parsely-Pot grown 50c per doz.

Cauliflower-Early Snowball most popular variety grown 25c per doz., \$1.50 per 100 .

Celery-Early Golden Plume-Self blanching, delicious nutty flavor, good shipper, 25̌c per doz. $\$ 2.00$ per 100 .

Mid-Season Golden Self Blanching-Good size very tender $\mathbf{2 5}$ c per doz, $\$ \mathbf{\$ 1 . 5 0}$ per 100 .

Late Golden Self Blanching-Fine keeper for midwinter use $\mathbf{2 5}$ c per doz, \$1.50 per 100 .

Cucumbers-Pickling variety 3 inch pots $10 \mathrm{c}$ each, $\$ 1.00$ per doz.

Long Green-For slicing 3 inch pots 10c, each, $\$ 1.00$ per doz.

Lettuce-Plants grown in pots 50c per doz.

Onion Plants- White, grow a few and raise some prize onions, $\$ 1.00$ per 100 .

Kohli Rabi-15̄c per doz, \$1.00 per 100 .

Brussels Sprouts-25c per doz, \$1.50 per 100 . 


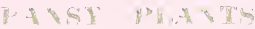

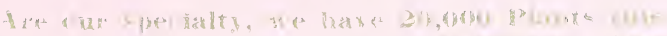

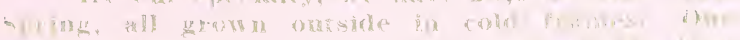

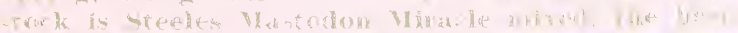

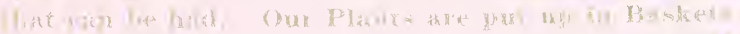

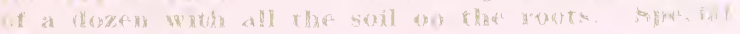

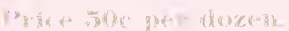

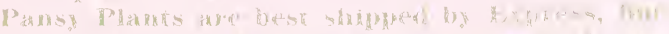

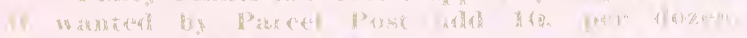

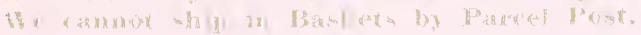

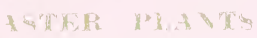

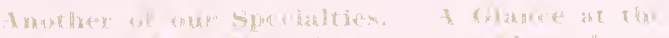

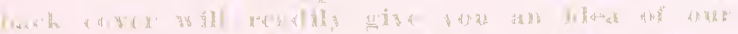

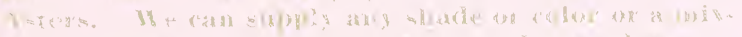

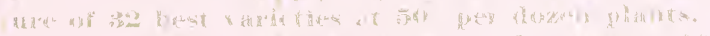

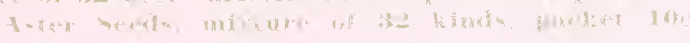

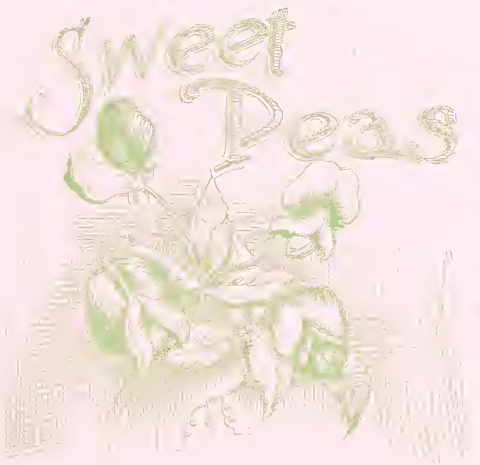

$$
\begin{aligned}
& \text { - I. H. W P R A } \\
& \text { क ज्ञाtil }
\end{aligned}
$$

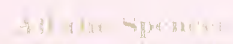
in whing in wht

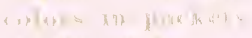

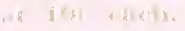

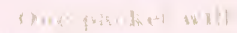

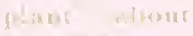

$$
\begin{aligned}
& \text { fent } x+1+\sin
\end{aligned}
$$

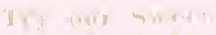

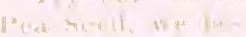

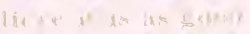

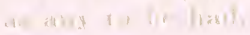

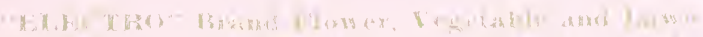

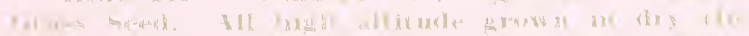

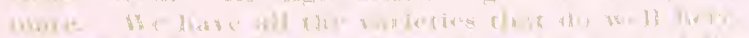

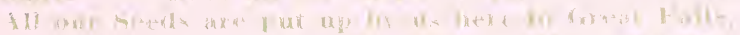

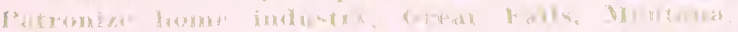

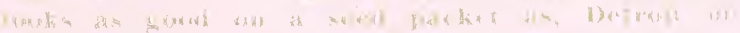

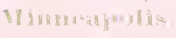

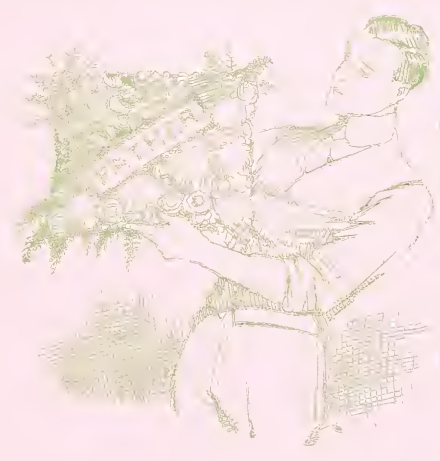

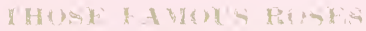

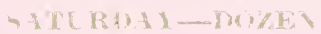

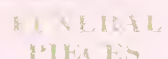

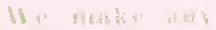

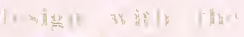
it thation al wh tilew -

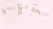

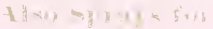

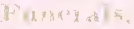

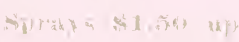

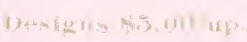

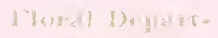
ic

\section{$95 \mathrm{C}$}

ELECTRIC CITY CONSERVATORY

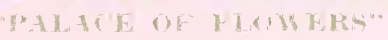

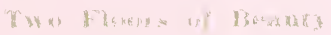

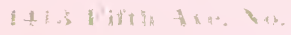

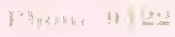




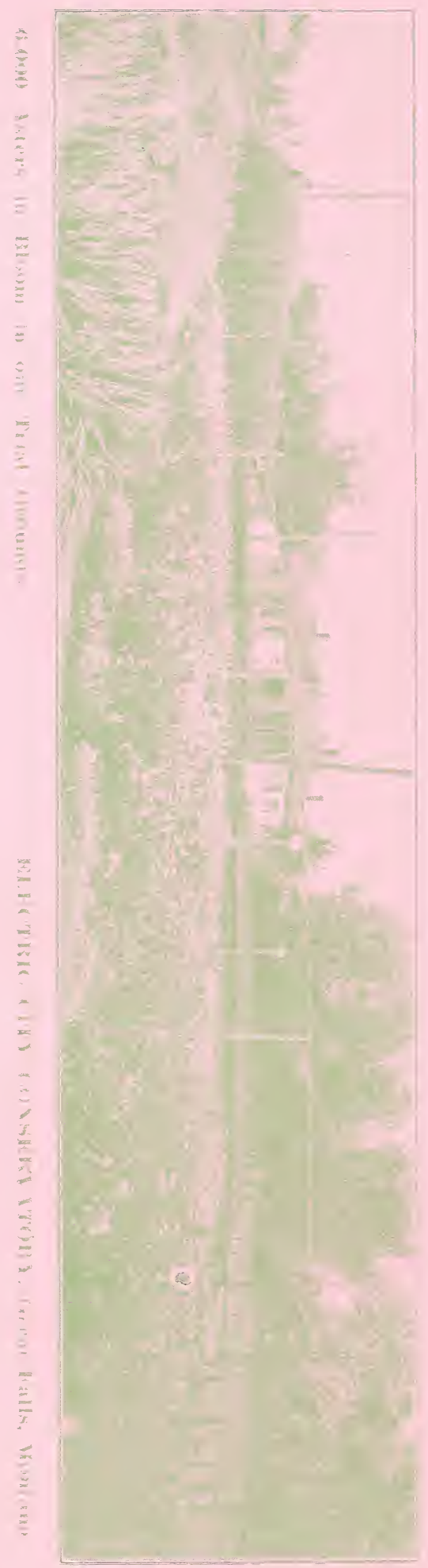

